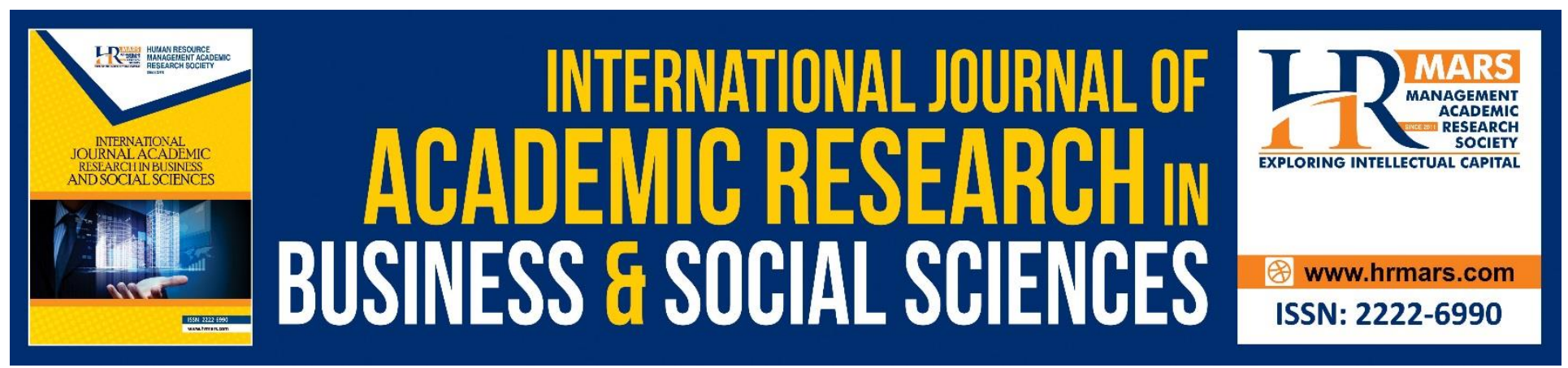

\title{
Accessing Market Entry Strategy in Emerging Markets: A Case Study of Edel Technology Consulting Limited
}

\section{Alhassan Musah, Bernard Badu-Acquah, Abass Yusif}

To Link this Article: http://dx.doi.org/10.6007/IJARBSS/v9-i1/5465

DOI: $10.6007 /$ IJARBSS/v9-i1/5465

Received: 30 Dec 2018, Revised: 19 Jan 2019, Accepted: 06 Feb 2019

Published Online: 10 Feb 2019

In-Text Citation: (Musah, Badu-Acquah, \& Yusif, 2019)

To Cite this Article: Musah, A., Badu-Acquah, B., \& Yusif, A. (2019). Accessing Market Entry Strategy in Emerging Markets: A Case Study of Edel Technology Consulting Limited. International Journal of Academic Research in Business and Social Sciences, 9(1), 646-659.

\section{Copyright: (C) 2019 The Author(s)}

Published by Human Resource Management Academic Research Society (www.hrmars.com) This article is published under the Creative Commons Attribution (CC BY 4.0) license. Anyone may reproduce, distribute, translate and create derivative works of this article (for both commercial and non-commercial purposes), subject to full attribution to the original publication and authors. The full terms of this license may be seen at: http://creativecommons.org/licences/by/4.0/legalcode

$$
\text { Vol. 9, No. 1, 2019, Pg. } 646 \text { - } 659
$$

Full Terms \& Conditions of access and use can be found at http://hrmars.com/index.php/pages/detail/publication-ethics 


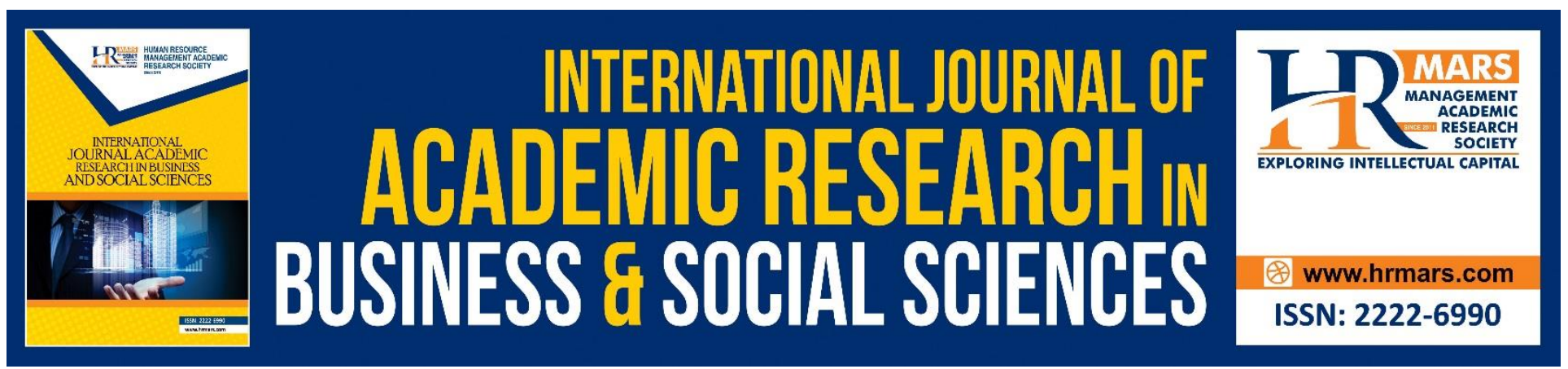

\title{
Accessing Market Entry Strategy in Emerging Markets: A Case Study of Edel Technology Consulting Limited
}

\author{
Alhassan Musah \\ Lecturer: Dominion University College, PMB CT 69, Accra. Email: a.musah@duc.edu.gh \\ Bernard Badu-Acquah
}

PhD Candidate: CASS Europe Institute of Management. Email: brnrdacquah@yahoo.com

\author{
Abass Yusif \\ Administrator: Nsawora Edumafua Senior High School. Email: yusifabass285@gmail.com
}

\begin{abstract}
Edel Technology Consulting is an IT and Management Consulting firm with operations in at least four countries that seeks to expand its operations into emerging markets to take advantage of the huge growth potential. The study examined the appropriate market entry strategy for Edel Technology Consulting into emerging markets, the potential barriers to entry and how those strategies will affect the survival of the firm.

The study through a purposive sampling technique sampled 25 respondents from the firm who are in senior management position and middle level management positions for their views on the subject matter.

The results of the study revealed that Greenfield strategy is the most favoured emerging market entry strategy for Management of Edel Technology Consulting. This was followed by network relationship and joint ventures. Majority of management of the firm did not favour acquisition strategy as it does not work well for professional firms. On the matter of the barrier to entry, the study reported that language barrier, cultural barriers, government policies and regulations in the area of local content, enforcement of copyrights among others and cost of face to face communication were the major barriers to entry into emerging markets for Edel Technology Consulting. The results also show that the market entry strategies have implications on the future growth and survival of the firm.
\end{abstract}

Keywords: Market entry, Strategy, Emerging market, Developing country 


\section{Introduction}

Business in today's global environment irrespective of their size or their product or services wants to go international (Amdam, 2009). Rahman and Tantu (2011) argue that internationalization of companies is growing at a faster pace than expected. Holtbrügge and Baron (2013) posits that comparative research on the potential of emerging markets is very expensive for most marketers as a result of the multitude of diverse markets for which there are available research. This notwithstanding, innovative companies are willing to enter emerging markets that are mostly ignored because of their potential for growth through investment and sourcing potentials (Deng, 2009; Peng, 2008). The choice of method to enter these emerging markets is a strategic decision for international businesses (Tsai and Eisingerich, 2010; Rahman and Tantu, 2011). Various studies have examined why firms go international and Thompson et al. (2005) as cited in Rahman and Tantu (2011) summarized these reasons to include; getting access to new customers to boost sales and revenue, achieving lower cost and boosting competitiveness, spread risk, and capitalize on the firm core competencies. What factors determines an organization market entry strategy has been a subject of academic debate with various views on what firms take into consideration in their market entry strategies (Meyer et al. 2008). These factors vary from one study to the other and from one industry to the other. New and smaller company faces grater obstacles in their quest to go international to emerging markets despites the potential of these markets (Sun, 2010). Companies entering new market, must first segment the market, survey the needs and taste of the said potential consumers and develop a unique product that will better service the needs of the market. This is the dilemma Edel Technologies faces in its quest to go international. Edel Technologies is an indigenous wholly owned Ghanaian firm in the technology consulting industry offering IT and consulting services to business organization. Since its formation, Edel Technologies has been referred to as the creator and leader of business innovation from pioneering both local and sub-regional delivery of IT models and software's. The company operates in an industry that is relatively young in Africa but with more competitors across the globe. The level of competition will even increase when the company goes international especially in emerging markets which have become the target markets for most business. This calls for the right entry strategy to ensure that the company remains competitive even on those new markets.

\section{Problem Statement}

Rahman and Tantu (2011) cited Thompson et al. (2005) who argues that when organizations are going international, they need to answer questions such as; who are we?, where do we want to go?, and how will we go there. The answer to the first two questions gives a sense of the firm core competencies and the firm expansion strategy with regards to international markets. The traditional market selection strategies have relied on macroeconomic and political factors but ignore critical factors such as emerging market dynamism and future potential as a result of rapid growth, specific sectors and market receptiveness (Elg et al. 2008; Meyer et al. 2008). Other strands of literature have examined the characteristics of the firm entering the new market and its resource capabilities (Rahman and Tantu, 2011; Khanna and Palepu, 2010). Meyer et al. (2008) and Demirbag et al. 2008) argue that even though firm characteristics and resource capabilities are important factors, recent literature have suggested that firm strategies for entering emerging markets are moderated by 
context of the market. These studies argue that institutions in the host country and the economy of the host country play a critical role in a firm foreign market entry strategy (Peng et al. 2008; Peng, 2012; Hoskisson et al. 2013). These considerations are even more important for entering into emerging markets (Meyer at el. 2008). It is important to add that little or no study have been conducted on market entry strategies by firms in Ghana in emerging markets. This presents a research gap in knowledge that needs to be explored. Most studies on market entry strategies into emerging markets usually involve developed markets to emerging markets or emerging market into another emerging market (Meyer et al. 2008; Meyer, 2011; Freeman and Sandwall, 2008; Ogbeide, 2018).

This study assumes that institutional development or under development in emerging economies affects market entry strategies and also investor need for local resources affect entry strategies. The study therefore adopts a more integrative approach which involves institutional effect and their integration with resource based considerations. In this regard the study focuses on the effectiveness of the market in facilitating access to the desired resources. Edel consulting currently have operations in four different markets but they are not emerging markets. The firm have the intentions of entering some merging markets in the new future to take advantage of the growth prospects in these markets and to strategically position itself for future growth. However, apart from the United Kingdom (UK), all the other markets of the company are developing markets with different characterise to emerging markets. Even though the firm has so far succeeded in these markets, it is important to see how the company can replicate that success in emerging markets. The study therefore examined how entry strategies such as acquisitions, joint ventures and Greenfield which are all component of foreign direct investment can be utilised by Edel Consulting in entering emerging markets. The study also looks at barriers to entry into emerging markets especially from the point of view of a professional firm like Edel Consulting and from a developing country like Ghana. The purpose of the study is to examine how various market entry strategies such as acquisitions, joint ventures and Greenfield as well as effective marketing strategies that can be adopted by Edel Consulting Ltd to enter some selected emerging markets.

\section{Objectives of the Study}

The specific objectives of the study include;

1. To examine the applicability of acquisitions, joint ventures and Greenfield entry strategies for Edel Consulting in emerging markets

2. To examine the potential barriers for Edel Consulting Ltd for entering into emerging markets

3. To examine the impact of these strategies on the survival and performance of Edel Consulting Ltd

\section{Significance of the Study}

The study makes significant contributions in the area of literature and practice. The study addresses the research gap in market entry strategies by firms in Ghana into emerging markets. The study also extend previous studies that have focused on specific factors that firms must take into account in entering emerging markets to include both traditional factors and other marketing considerations that firms in Ghana must adopt in entering emerging markets. This research work seeks to assess and analyze the impact of market entry barriers that on the performance and survival of start-up. The 
study highlights the appropriate marketing entry strategies that propel organizational performance and survival in any given market. The results of the study are useful to local professional firms that want to expand their operations to other emerging markets.

The study will help guide marketers and managers when making market entry decisions most especially about product development and design as well as other marketing strategies such as pricing policies. It will also provide a better understanding and analyses of the market environment and guide businesses going forward. The study will serve as basis for future research in Ghana on market entry strategies of Ghanaian companies in emerging markets.

\section{Literature Review}

\section{Institutional theory and Market entry strategy}

The literature review examines market entry strategies into emerging markets from the perspective of institutional of institutional theory by arguing that the institutional framework in these emerging markets has implications on the choice of appropriate market entry strategy that will make the firm competitive and successful. Holtbrugge and Baron (2013) argued that international management research has established that the institutional context within which a firm operates influences its market entry strategies and outcomes. The institutional environment includes both formal and informal forces in the form of laws, regulations, property rights, and normative structure among others which affect the organizational and human behaviour (Peng, 2009). The choice and entry mode is usually affected by these factors as well as the type and nature of the organizational than intends to go international (Meyer et al. 2008). Holtbrugge and Baron (2013) posits that one important decision for an organization entering international market especially emerging markets is the value of activities that it intends to transfer abroad. Literature on choice of activity mode distinguishes between foreign production and export (Hennart, 2008). This model will however not be applicable to professional organizational like Accounting and management consulting firms as is the case in this study. The professional firms that want to use export strategy will still require some presence in the market but rely on expertise from home country. Johnson and Duhamel (2009) argues that foreign firms exporting their good and services to emerging markets faces challenges such as government failure to provide consistent export policy, poor economic conditions, local content requirement and tariffs, uncertainty as a result of high currency fluctuations among others. The use of foreign production is more capital intensive in terms of relocating facilities abroad (Holtbrugge and Baron, 2013). However, in the case of a professional and consulting firm, the cost of relocating could be relatively lower compared to manufacturing companies (Freeman and Sandwell, 2008). Foreign production strategy has high management complexity and a higher exposure to political and economic risk as a result of institutional weakness. But on the other hand, it allows for greater control and the firm's operations and activities (Freeman and Sandwell, 2008). Holtbrugge and Baron (2013) posits that the advantage of such control in the context of the BRIC countries include the protection of resources from patent theft and enjoyment of economies of scale in markets with high growth potential. These are very critical especially a technology consulting firm like Edel Technology Consulting. 
INTERNATIONAL JOURNAL OF ACADEMIC RESEARCH IN BUSINESS AND SOCIAL SCIENCES

Vol. 9, No. 1, Jan, 2019, E-ISSN: 2222-6990 @ 2019 HRMARS

\section{Market entry Strategies}

Various market strategies have been adopted by multinational corporations entering emerging markets like China, Brazil, India, Mexico, and South Africa among others. Notable among these market entry strategies include acquisition, joint ventures, Greenfield entry strategies, network relationship (Holtbrugge and Baron, 2013; Freeman and Sandwell, 2008; Peng, 2009).

In terms of acquisition, the critical question to ask is whether the firm should use wholly owned subsidiary or share ownership as a form of control and market entry strategy. Firms that enter foreign market through wholly owned subsidiaries benefit from managerial control and autonomy (Holtbrugge and Baron, 2013). Market entry strategy based on acquisition model is always sensitive to the efficiency if the financial markets and corporate control (Peng, 2009). Institutional framework always facilities the financial market by ensuring transparency and predictability as well as contract enforcement (Meyer et al. 2008). This strategy is good especially in markets with less legal protection and intellectual property rights. The disadvantage is that they may suffer from the liability of foreignness where they don't have a legitimate local partner (Slangen and van Tulder, 2009). From an institutional perspective, the choice of ownership mode could reduce institutional pressures and other risk factors such as political risk ect. For instance emerging markets like Brazil have high incidence of unemployment, political instability, high corruption and challenges with social and tax reforms even though they have a huge market potential that every multinational company will want to take advantage off. Also, in a country like Russia, corruption is a serious issue and there is the presence of competing informal institutions which can affect multinational operating there (Bressler, 2009). In India, issue of terrorism, tensed relationship between Pakistan and Bangladesh among other risk factors whiles China and South Africa also have their own fair share of risk factors (Holtbrugge and Baron, 2013). All these factors must be properly evaluated before choosing an appropriate market entry strategy.

Firms can also enter foreign markets through joint ventures. This market entry strategy has the potential to reduce risk associated with foreignness as well as gain some legitimacy as there is high level of local content participation. Joint venture allows the firm access to local resources (Meyer et al. 2008). From a technology and consulting and professional firm, this market entry strategy is most appropriate as it allows for closer connection and networking with relevant industry players and stakeholders in the emerging market (Freeman and Sanwell, 2008). Their study argues that service organizations are unique and different which have affected their export drive. Meyer et al. (2008) argue that most studies show that service organizations that use joint ventures or some form of coownership as a market entry strategy tend to choose countries that are less developed in the area of service that they provide. For instance, Kim et al. (2012) study revealed that most Korean firms that go international like to operate in less developed economies where they have superior resource advantage. They however, go to more developed countries with a view to learn on build on their existing capabilities and expertise.

Firms can also enter foreign and emerging markets through Greenfield acquisitions or investments. Acquisition strategy allows easy and quick market presence and also knowledge to local market (Holtbrugge and Baron, 2013). It allows the multinational organization to build on the existing facilities and resource of the local firm acquires and uses their connection to expand the firm. Some international accounting and audit firms have adopted this strategy in entering some of the most 
challenging markets to enter (Freeman and Sandwell, 2008). The dangers of Greenfield acquisitions are the risk of collapse as a result of organizational and cultural misfit (Meyer, 2011). The institutional framework in most emerging economies increases information asymmetry which affects transparency and enforcement of transactions (Meyer, 2011). In some emerging countries, host government have restrictions on acquisitions of local firms making it difficult for multinationals to rely on it as a market entry strategy in emerging markets (Holtbrugge and Baron, 2013).

\section{Barriers to entry into Emerging markets}

Literature have shown that there are significant barriers to entry into emerging markets (Meyer, 2011; Freeman and Sandwell, 2008; Peng, 2009). Most of these barriers to entry include but not limited to mercurial government policies, political risk, funds restrictions. Among these barriers to entry into emerging markets, government policy and regulation are the major barriers to entry in emerging markets (Johnson and Tellis, 2008; Freeman and Sandwell, 2008). Another big barrier identified in literature is cultural barriers and the issue of language differences. For emerging market like South Africa and India where the official language is English, Edel Technology and consulting can easily fit even though the cultural difference still remains. Freeman and Sandwell (2008) argue that language very is a major barrier for consulting and service organization as their activities requires constant interactions in a medium that is understandable by all parties. Some studies even found that in countries such as Hong Kong, Taiwan and Singapore language still is a significant barrier that affect companies' success in emerging markets as its impacts quality of service delivery. The cultural barriers also have implications for work relationship especially in a joint venture type of entry strategy or any such similar market entry strategy into any of the emerging markets. Cultural and language as well as other barriers can derail the success of professional organizations entering emerging markets.

\section{Methodology \\ Research Design and Strategy}

This study is a case study. Yin (2017) explained case study method as an empirical inquiry that instigates contemporary phenomena within its real life context, thus when the boundaries between the phenomenon and context are not clearly evident and in which multiple sources of evidence are used. The case study approach allows for a more detailed analysis of a phenomenon within specific context for proper inferences and conclusions to be drawn (Creswell, 2012).

In terms of research design, the study adopts the mixed method approach combining the strength of both qualitative and quantitative analysis. A study by Klassen et al. (2012) defines mixed method approach as "one in which the researcher tends to base knowledge claims on pragmatic grounds. The data to be collected involves gathering both numeric information as well as test information so that the final database represents both qualitative and quantitative information". It involves integrating quantitative and qualitative methods of research. Within the context of Ghana, the study can be seen as an exploratory study that seeks to evaluate market entry strategies appropriate for a local information technology consulting firm with operations in other countries like the Sierra Leone, Nigeria and the UK. Studies on professional organizations like Edel entering emerging markets have been viewed from a perspective of developed countries entering emerging markets. The case of Edel 
INTERNATIONAL JOURNAL OF ACADEMIC RESEARCH IN BUSINESS AND SOCIAL SCIENCES

Vol. 9, No. 1, Jan, 2019, E-ISSN: 2222-6990 (C) 2019 HRMARS

Consulting is unique as the company is moving from developing country to developed and emerging markets.

\section{Data Collection}

This study collected data from both primary and secondary source. Primary data was collected using interview and questionnaire to identify issues relevant to the study. The questionnaires were administered personally to twenty-five (25) respondents consisting of ten (10) management staff and fifteen (15) other employees of Edel Technologies. Questionnaire administration and interviews were carried out at the Head Quarters of the company by the researcher. This allowed the researchers to explain to the respondents the essence of the research and also provide clarity to areas respondents may have difficulties. Secondary data was sourced through the use of books, articles, journals, and hand-outs on market entry strategies.

\section{Sample frame and Sampling technique}

The sample frame for the study includes all employees of Edel Consulting Ltd. Purposive/subjective sampling was used to select the respondents since they have the relevant information the researcher needs. This is a non-probability sample that selects a given population based on characteristics of the population and the objective of the study. The study seeks to examine market entry strategies into emerging markets which presuppose that not all employees have relevant knowledge on the subject matter. The purposive sampling technique allows the researcher to sample only respondents who have the knowledge and expertise on the subject matter. Since market entry strategy is a strategic decision, top and middle managers and sectional heads were involved and as such were sampled for the study.

\section{Data Analysis and Presentation}

After the desired data was collected, there is the need to analyse it. Questionnaires and interviews that were collected from the field would be used in the data analysis. The data obtained from the interviews and questionnaires were be sorted, edited and analyzed into frequency distribution tables, percentages and to ensure easy understanding of the analyses. The qualitative data were also analysed according to the major themes of the study and in line with the objectives of the study.

\section{Analysis and Discussion of findings}

This section present an analysis of data collected from respondents who are managers and senior employees of Edel Technology Consulting limited. In all 20 out of a target of 25 responded to the questionnaire and interviews. The data was analysed both quantitatively through the use of percentages to aggregate responses on a subject matter; and qualitatively from the responses attained from the interview. Excerpts of the secondary data that supports the objectives are quoted in the analysis for clearer understanding of the responses obtained. The results of the Reponses are organized into themes in line with the objectives of the study; but first, a brief summary of the respondent biography. 20 out of the $25 \%$ targeted respondents were surveyed representing $80 \%$ turnout. 
INTERNATIONAL JOURNAL OF ACADEMIC RESEARCH IN BUSINESS AND SOCIAL SCIENCES

Vol. 9, No. 1, Jan, 2019, E-ISSN: 2222-6990 @ 2019 HRMARS

Table 1 Years of employment with the organization

\begin{tabular}{lrr}
\hline YEARS & FREQUENCY & \multicolumn{2}{c}{ PERCENTAGE } \\
\hline \hline 1YEAR- 2 YEARS & 4 & 20.00 \\
3 YEARS - 5 YEARS & 8 & 40 \\
6 YEARS AND ABOVE & 8 & 40 \\
& & \\
\hline
\end{tabular}

Source: Field data, 2018

As illustrated in Table 4.2.1 above, it is evident that over $20 \%$ of the respondents have worked for the organization for 1 to 2 years, $40 \%$ of the entire population have worked for the case organization for 3 to 5 years of age, and the remaining $40 \%$ have worked for organization for over 6 years. These results suggest that the case organization have good employee retention systems. The results also imply that the sampled respondent have been with the organization and understand the future direction of the company as well as their capabilities sand are therefore qualified to provide responses to the questions.

\section{Emerging Market entry strategy for Edel Technology Consulting}

On the first objective of the study which seeks to evaluate emerging markets entry strategies for Edel Technology Consulting. The response were organised into themes in line with the objectives of the study which is to examine market entry strategies into emerging markets for $s$ service and professional consulting firm like Edel Technology Consulting and how the entry strategies affect the survival of the firm. The responses on the first them and objective which is market entry strategy into emerging markets for Edel Consulting revealed that majority of respondent argues that the market entry strategy depended largely on the characteristic of the specific emerging market they are entering. On the research question one senior manager and respondent remarked: "At Edel Consulting we don't have a template markets entry strategy for markets with similar characteristics. What we do is to identity opportunities in the market we hope to enter and based on the unique situations in the market we adapt and chose the most appropriate strategy". The view of this respondent shows that the company does not rely on what experts in the industry just say is the best approach but they try to examine the suitability of the approach to their circumstance. A follow up was whether the company was more likely to choose acquisition, joint venture or Greenfield entry strategy. The responses to this question by majority of the respondents show that the company does not fancy acquisitions especially on emerging economies where language barrier exists. On this issue one respondent remarked: at Edel Technology Consulting the similarities of the market to Ghana is very important in deciding our market entry strategy. We have always preferred using Greenfield or joint venture in markets where there is huge cultural, language and other barriers. But for emerging market with high difference to Ghana in terms language, culture and way of doing business, joint ventures and other similar collaborations to take care of discriminations and other local content polities. The company currently have operations in Nigeria, the UK and other West African countries where their main entry strategy have been Greenfield entry strategy. Acquisitions among professional firms like Edel Consulting are very rare according to the respondents and as such you 
either collaborate through joint venture or other similar arrangement or use Greenfield entry strategy. The respondent revealed that the company have plans of entering some emerging markets like South Africa and some of the BRIC countries but are still evaluating the appropriate market entry strategy. The entry strategy of Edel Consulting to emerging markets like China, Brazil, Venezuala and other countries that do not have English as their official language is based on collaborations an joint ventures. The results of the findings of this study is contrary to the findings of Holtbrugge and Baron (2013) where their study reported that most companies preferred to enter emerging markets like China through wholly owned subsidiaries or acquisitions because institutional changes make local partners irrelevant in these markets. The results however may be applicable to manufacturing or trading organizations as Freeman and Sandwell (2008) found that professional organizations and firms best strategy to entering new markets is collaboration as acquisitions might not help the firm get the needed connections and hence getting clients. They further argued that unless the emerging market the company intends to operates have large foreign multinational from the country of origin where the firm is coming from, then the company can still go ahead with acquisition or setting up a wholly owned subsidiaries and still succeed. To this end, the key elements of positioning, timing and orientating are critical in organizations market entry strategies.

Respondents were asked to rank which of the market entry strategies into emerging market in most appropriate for the company. The table below presents a summary of the ranking from respondents.

\begin{tabular}{lrrr}
\hline Market Entry Strategy & Frequency & Percent & Rank \\
\hline Greenfield Strategy & 12 & $48 \%$ & 1 \\
Network relationship & 6 & $24 \%$ & 2 \\
Joint venture & 4 & $16 \%$ & 3 \\
Acquisitions & 3 & $12 \%$ & 4 \\
\cline { 2 - 3 } & 25 & $100 \%$ & \\
\hline
\end{tabular}

Source: Field data, 2018

The ranking from the responses shows that majority of respondents favour Greenfield market entry strategy, followed by network relationship and joint venture arrangements. The least emerging market entry approach respondent ranked was acquisitions.

\section{Barriers to entry in Emerging Markets}

The respondents indicated that the one of the major barriers to entry into most emerging market is language barrier. But this language barrier is not visible in countries that have English as their official language. The respondent argued that so far all their operations have been limited to mostly English speaking countries or countries whose official language is English. However, the company have executed some contracts in Francophone countries in Africa for multinational companies who use English for international transactions. These contracts have mostly been executed through collaborations with local firms or sometimes Edel Technology Consulting won those contracts through international competitive bidding. Language barriers are more important when firms want to set up subsidiaries and the best way to overcome that is through joint venture and collaborations. The second barrier to entry into international market in the form of emerging market is government policy and regulations. Most respondents argued that government policies and regulations especially with regards to local content affect their ability to enter certain emerging markets. It's emerged that 
countries like India and China prefer using local technology solutions and as such will prefer using local firms to international firms. Government policy and regulations in the area of copyright enforcement and protection of similar rights are weak in some emerging countries. This is particularly the case for foreign companies entering into some of these emerging markets through acquisitions and wholly owned subsidiaries.

One other barrier to entry into emerging markets for professional firms like Edel Technology Consulting is the cost of face to face communication. This medium of communication helps to avoid misunderstanding of non-verbal cues which is one of the problems associated with electronic form of communication. The cost of travelling to overseas to visit customers and clients is expensive for foreign firms like Edel Technology consulting. One respondents argued that "our experience in some countries where our clients in overseas, we most often have to arrange for a face to face discussion at a place of their convenience which come with additional cost. So some time the company decides on which markets to meet clients based on the cost involved". The results are somewhat consistent with the findings of Freeman and Sandwell (2008) where it was found that professional law firms entering emerging markets had cost to face to face as a major barrier. It however appears this barrier in question is synonymous with professional firms as studies on manufacturing and trading firms dis not have this as a barrier to market entry into emerging markets.

There is higher risk for entering into emerging markets like China and Brazil even though they have high growth potential and more multinational firms are moving there which can be potential clients of Edel Technology Consulting.

\section{Effect of Market entry strategy on firm Survival}

Respondent were asked about their view on the impact that a chosen market entry strategy can have on their survival of the firm. Majority on the respondents argues that the choice of market entry strategy impact on their ability to succeed and hence the future growth and survival of the firm. The respondents were however a bit hesitant to admit that it can affect the survival of the firm. They believe it can have negative effect on the firm but not necessarily their survival as they have already established themselves in at least four major markets. Failing in one or two emerging markets cannot necessarily affect their survival of the firm but can affect their image and reputation.

\section{Conclusion and Recommendation}

The study examined the market entry strategies for Edel Technology Consulting into emerging markets and the barriers to entry and well as the effect of these strategies on the survival of the firm. The results of the study showed that Edel Technology consulting prefers Greenfield market entry strategy or a network market entry strategy or joint ventures rather than through acquisitions. The study also revealed that the major barriers to entry for Edel into Emerging markets were language barrier, cultural barrier, government policies and cost of face to face communication. The results of the study were similar to studies on market entry strategies for professional firms but ad variance with manufacturing and trading firms. The study also revealed that the entry strategies have implications on the future performance of the company in terms of growth but were hesitant to link it to the survival of the firm. Market entry for professional firms into emerging market with language and cultural difference poses a greater risk and for that matter countries like China and Brazil are 
considered high risk compared to emerging countries like South Africa and India. The study makes significant contributions to literature on market entry strategies for firms in developing countries into emerging markets. The study recommends that Ghanaian companies should take into consideration language and cultural barriers when planning an entry strategy into emerging markets. The results call for more studies in the area of market entry strategies for firms from developing countries like Edel into Emerging and developed markets using a larger sample of firms.

\section{Limitations of the Study}

The first limitation that was observed in the study is the overreliance on self-reported measures of participants. A major disadvantage of this method of data collection is that it is subject to a common method or the source error. Although self-reports measures have been found to be reliable, most participants normally answer questions based on what they perceive as a socially desired response and this may bias responses of participants and consequently affect the actual relationship between the variables.

Secondly, a larger sample size would be appropriate to establish the relationship between the variables in future studies as this would lead to more accurate information that would represent a better view of the larger society

\section{References}

Amdam, R. P. (2009). The internationalisation process theory and the internationalisation of Norwegian firms, 1945 to 1980. Business History, 51(3), 445-461.

Bressler, M. S. (2009). The impact of crime on business: A model for prevention, detection \& remedy. Journal of management and Marketing Research, 2, 1.

Chen, Y. R., Yang, C., Hsu, S. M., \& Wang, Y. D. (2009). Entry mode choice in China's regional distribution markets: Institution vs. transaction costs perspectives. Industrial Marketing Management, 38(7), 702-713.

Creswell, J. W. (2012). Collecting qualitative data. Educational Research: Planning, Conducting, and Evaluating Quantitative and Qualitative Research. Fourth ed. Boston: Pearson, 204-35.

Demirbag, M., Tatoglu, E., \& Glaister, K. W. (2008). Factors affecting perceptions of the choice between acquisition and greenfield entry: The case of Western FDI in an emerging market. Management International Review, 48(1), 5-38.

Deng, P. (2009). Why do Chinese firms tend to acquire strategic assets in international expansion?. Journal of World Business, 44(1), 74-84.

Elg, U., Ghauri, P. N., \& Tarnovskaya, V. (2008). The role of networks and matching in market entry to emerging retail markets. International Marketing Review, 25(6), 674-699.

Estrin, S., Baghdasaryan, D., \& Meyer, K. E. (2009). The impact of institutional and human resource distance on international entry strategies. Journal of Management Studies, 46(7), 1171-1196.

Freeman, S., \& Sandwell, M. (2008). Professional service firms entering emerging markets: the role of network relationships. Journal of Services Marketing, 22(3), 198-212.

Hennart, J. F., \& Slangen, A. H. (2015). Yes, we really do need more entry mode studies! A commentary on Shaver. Journal of International Business Studies, 46(1), 114-122. 
INTERNATIONAL JOURNAL OF ACADEMIC RESEARCH IN BUSINESS AND SOCIAL SCIENCES

Vol. 9, No. 1, Jan, 2019, E-ISSN: 2222-6990 @ 2019 HRMARS

Holtbrügge, D., \& Baron, A. (2013). Market entry strategies in emerging markets: An institutional study in the BRIC countries. Thunderbird International Business Review, 55(3), 237-252.

Holtbrügge, D., \& Baron, A. (2013). Market entry strategies in emerging markets: An institutional study in the BRIC countries. Thunderbird International Business Review, 55(3), 237-252.

Hoskisson, R. E., Wright, M., Filatotchev, I., \& Peng, M. W. (2013). Emerging multinationals from midrange economies: The influence of institutions and factor markets. Journal of Management Studies, 50(7), 1295-1321.

Hoskisson, R. E., Wright, M., Filatotchev, I., \& Peng, M. W. (2013). Emerging multinationals from midrange economies: The influence of institutions and factor markets. Journal of Management Studies, 50(7), 1295-1321.

Khanna, T., \& Palepu, K. G. (2010). Winning in emerging markets: A road map for strategy and execution. Harvard Business Press.

Kim, Y. K., Lee, K., Park, W. G., \& Choo, K. (2012). Appropriate intellectual property protection and economic growth in countries at different levels of development. Research policy, 41(2), 358-375.

Klassen, A. C., Creswell, J., Clark, V. L. P., Smith, K. C., \& Meissner, H. I. (2012). Best practices in mixed methods for quality of life research. Quality of Life Research, 21(3), 377-380.

Li Sun, S. (2009). Internationalization strategy of MNEs from emerging economies: The case of Huawei. Multinational Business Review, 17(2), 129-156.

Meyer, K. E., Estrin, S., Bhaumik, S. K., \& Peng, M. W. (2009). Institutions, resources, and entry strategies in emerging economies. Strategic management journal, 30(1), 61-80.

Meyer, K. E., Mudambi, R., \& Narula, R. (2011). Multinational enterprises and local contexts: The opportunities and challenges of multiple embeddedness. Journal of management studies, 48(2), 235252.

Musah, A., Badu-Acquah, B., \& Yusif, A. (2019). Accessing Market Entry Strategy in Emerging Markets: A Case Study of Edel Technology Consulting Limited. International Journal of Academic Research in Business and Social Sciences, 9(1), 646-659.

Peng, M. W. (2012). The global strategy of emerging multinationals from China. Global Strategy Journal, 2(2), 97-107.

Peng, M. W., Wang, D. Y., \& Jiang, Y. (2008). An institution-based view of international business strategy: A focus on emerging economies. Journal of international business studies, 39(5), 920-936.

Sheth, J. N. (2011). Impact of emerging markets on marketing: Rethinking existing perspectives and practices. Journal of Marketing, 75(4), 166-182.

Slangen, A. H., \& Hennart, J. F. (2008). Do multinationals really prefer to enter culturally distant countries through greenfields rather than through acquisitions? The role of parent experience and subsidiary autonomy. Journal of International Business Studies, 39(3), 472-490.

Slangen, A. H., \& Van Tulder, R. J. (2009). Cultural distance, political risk, or governance quality? Towards a more accurate conceptualization and measurement of external uncertainty in foreign entry mode research. International business review, 18(3), 276-291.

Tantu, F., \& Rahman, M. (2011). Emerging markets: A case study on foreign market entry in Bangladesh. 
INTERNATIONAL JOURNAL OF ACADEMIC RESEARCH IN BUSINESS AND SOCIAL SCIENCES Vol. 9, No. 1, Jan, 2019, E-ISSN: 2222-6990 @ 2019 HRMARS

Tantu, F., \& Rahman, M. (2011). Emerging markets: A case study on foreign market entry in Bangladesh in Thompson, A. A., Strickland, A. J., \& Gamble, J. E. (2007). Crafting and executing strategy. The quest for competitive advantage. Concepts and cases. 15th edition, New York, NY.

Tsai, H. T., \& Eisingerich, A. B. (2010). Internationalization strategies of emerging markets firms. California Management Review, 53(1), 114-135.

Yin, R. K. (2017). Case study research and applications: Design and methods. Sage publications. 